\title{
Oxidation-reduction reactions of simple hydroxamic acids and plutonium(IV) ions in nitric acid
}

\author{
By M. J. Carrott ${ }^{1}$, O. D. Fox ${ }^{1}$, G. LeGurun ${ }^{1}$, C. J. Jones ${ }^{1}$, C. Mason ${ }^{1}$, R. J. Taylor ${ }^{1} *$, F. P. L. Andrieux ${ }^{2}$ and C. Boxall $^{2}$ \\ ${ }^{1}$ British Technology Centre, Nexia Solutions, Sellafield, Seascale CA20 1PG, UK \\ 2 Centre for Materials Science, University of Central Lancashire, Preston PR1 2HE, UK
}

(Received June 4, 2007; accepted in revised form November 15, 2007)

\begin{abstract}
Formohydroxamic acid / Acetohydroxamic acid / Advanced purex / $\mathrm{Pu}(\mathrm{IV})$ reduction / Hydrolysis / Electrochemistry / Actinide separations
\end{abstract}

\begin{abstract}
Summary. Simple hydroxamic acids such as formo- and aceto-hydroxamic acids have been proposed as suitable reagents for the separation of either $\mathrm{Pu}$ and/or $\mathrm{Np}$ from $\mathrm{U}$ in modified or single cycle Purex based solvent extraction processes designed to meet the emerging requirements of advanced fuel cycles. The stability of these hydroxamic acids is dominated by their decomposition through acid hydrolysis. Kinetic studies of the acid hydrolysis of formo- and acetohydroxamic acids are reported in the absence and the presence of $\mathrm{Pu}(\mathrm{IV})$ ions. The slow reduction of these plutonium(IV) hydroxamate complexes to $\mathrm{Pu}(\mathrm{III})$ aquo-ions has been characterised by spectrophotometry and cyclic voltammetry. The reductions of $\mathrm{Pu}(\mathrm{IV})$ in the presence of FHA and AHA are consistent with a mechanism in which free hydroxamic acid in solution is hydrolysed whilst $\mathrm{Pu}(\mathrm{IV})$ ions remain fully complexed to hydroxamate ligands; then at some point close to a $1: 1 \mathrm{Pu}(\mathrm{IV}):$ XHA ratio, some free $\mathrm{Pu}^{4+}$ is released from the complex and reduction is initiated. Electrochemical and kinetic data suggest that the reductant is the hydroxamic acid rather than the hydroxylamine.
\end{abstract}

\section{Introduction}

Hydroxamic acids (XHA) are a particularly interesting class of organic ligands. They are $\mathrm{O}, \mathrm{O}$ donor ligands of general structure [RCONHOR'], and as such can be considered as hard Lewis bases capable of interacting strongly with a range of metal ions [e.g. see 1-5]. As well as their complexing properties, hydroxamic acids are hydroxylamine derivatives and are easily oxidized by metal ions such as $\mathrm{Np}(\mathrm{VI})[6,7]$. Consequently, applications of simple hydrophilic hydroxamic ligands $\left(\mathrm{R}=\mathrm{H}\right.$ or $\left.\mathrm{CH}_{3}\right)$ for the stripping of actinides in much simplified Purex solvent extraction flowsheets for advanced fuel cycles have been reported [8-11].

This paper describes aspects of the redox chemistry of formo- and aceto-hydroxamic acids (FHA, AHA) in the

\footnotetext{
*Author for correspondence

(E-mail: robin.j.taylor@nexiasolutions.com).
}

presence of $\mathrm{Pu}(\mathrm{IV})$ ions. The influences of these hydroxamic acids on the solvent extraction chemistry of $\mathrm{Pu}(\mathrm{IV})$ ions are to be reported in a companion paper [12].

\section{Experimental methods}

\subsection{Chemicals}

A $\mathrm{Pu}$ (III) stock solution was generated electrochemically from the stable $\mathrm{Pu}(\mathrm{IV})$ stock solution in nitric acid and the purities of $\mathrm{Pu}$ stock solutions were checked spectrophotometrically before use ( $\mathrm{Pu}$ stock solutions used Magnoxderived plutonium nitrate solutions). Uranyl nitrate solution was prepared from the crystals and hydroxylamine nitrate by the addition of stoichiometric amounts of $\mathrm{AgNO}_{3}$ to hydroxylamine chloride. $\mathrm{Fe}$ (III) was prepared from crystals of $\mathrm{Fe}\left(\mathrm{NO}_{3}\right) \cdot 9 \mathrm{H}_{2} \mathrm{O}$ (Sigma-Aldrich). Analytical grade reagents were used where available. FHA (custom synthesis, Tocris Cookson) and AHA (Sigma-Aldrich) solutions were prepared from the solids, the purity of synthesised FHA was verified from ${ }^{1} \mathrm{H}-\mathrm{NMR}$ in combination with analytical data. FHA and AHA crystals were stored in a refrigerator to minimise decomposition and all solutions were made up in distilled or deionised water when required.

\subsection{XHA hydrolysis}

The hydrolysis kinetics for FHA and AHA were measured using a colorimetric method $[13,14] . \mathrm{HNO}_{3}$ and XHA solutions were equilibrated at specific temperatures in a water bath prior to mixing. At intervals, small samples were taken and diluted in to excess $\mathrm{Fe}(\mathrm{III})$ solution $\left(0.01 \mathrm{M} \mathrm{HNO}_{3}\right)$. This simultaneously forms the Fe(III)-XHA complex and quenches the hydrolysis. The absorption spectrum of the red coloured complexes formed were then recorded and used to determine XHA concentration from a previously established calibration curve. The Fe(III)-FHA complex analysed showed a broad peak centred at $\sim 489 \mathrm{~nm}$ whilst the Fe(III)AHA complex had a peak maxima $\sim 499 \mathrm{~nm}$. Note that it was important to sample the $\mathrm{XHA}-\mathrm{HNO}_{3}$ solutions and to add the $\mathrm{Fe}$ (III) reagent separately to each sample, as we have shown elsewhere that the Fe(III)-XHA complex itself hydrolyses at a different rate than free XHA [15]. Standard kinetic methods were used to analyse the data [16]. 


\subsection{Plutonium(IV) - XHA reduction experiments}

Standard well established methods in plutonium chemistry and chemical kinetics were used throughout this part of our studies. Stock solutions were mixed in an optical cuvette and equilibrated at the desired temperature. (N.b. a last set of 5 experiments were performed at a later date using a Zeiss UV/Vis spectrometer coupled via fibre optics to a dipping optrode for direct measurement of a reaction solution of $25 \mathrm{~mL}$ volume in a glovebox). The reducing agent (hydroxylamine nitrate (HAN), XHA) was added last, the solutions mixed and the absorption spectra recorded over time. A water jacket connected to a thermostatically controlled water bath was used to maintain specific reaction temperatures in the cuvette. The reduction reaction was followed over time using the growth of the $\mathrm{Pu}(\mathrm{III})$ absorption band at $\sim 905 \mathrm{~nm}$ [17], because the intense Pu(IV)-XHA absorption peaks $[18,19]$ vary slightly depending on the actual speciation. The procedures were checked initially by validation against the well known $\mathrm{Pu}(\mathrm{IV})-\mathrm{HAN}$ reaction [20].

Certain difficulties encountered in these studies should be noted. In particular, obtaining reproducible and selfconsistent sets of experimental data did not prove to be straightforward. Particularly, in some early experiments reduction appeared to occur rather rapidly with FHA, often with no induction period. This was ascribed to two potential problems in the procedures, (a) the use of 'aged' XHA crystals which may have deteriorated during storage and (b) the use of heating to accelerate dissolution of XHA in concentrated stock solutions. These early experiments were therefore disregarded and (a) new batches of FHA and AHA were obtained and (b) less concentrated stock solutions were prepared under mild ambient conditions only. Interestingly, these failed experiments, however, do indicate the sensitivity of the system to XHA decomposition (hydrolysis), which will be discussed in detail in Sects. 3.1 and 3.2.

Ultimately, 78 useful kinetic experiments were performed; these can be described in categories according to the experimental parameters under investigation:

1. AHA experiments at ambient temperatures $(\sim 20$ or $25^{\circ} \mathrm{C}$ ) with (i) variable AHA and (ii) variable $\mathrm{HNO}_{3}$ concentrations.

2. AHA experiments at elevated temperatures $\left(40^{\circ} \mathrm{C}\right)$ with (i) variable $\mathrm{HNO}_{3}$, (ii) increasing ionic strength (added $\mathrm{NaNO}_{3}$ ), (iii) added $\mathrm{U}(\mathrm{VI})$ ions and (iv) varying initial [Pu].

3. AHA experiments in $1 \mathrm{M} \mathrm{HNO}_{3}$ at varying temperatures $\left(30-70^{\circ} \mathrm{C}\right)$.

4. AHA experiments with variable initial concentrations of $\mathrm{Pu}$ (III) $\left(40^{\circ} \mathrm{C}\right)$.

5. FHA experiments at $20{ }^{\circ} \mathrm{C}$ with (i) variable $\mathrm{HNO}_{3}$, (ii) increasing ionic strength (added $\mathrm{NaNO}_{3}$ ), (iii) added $\mathrm{U}(\mathrm{VI})$ ions, (iv) varying initial [Pu], (v) varying FHA.

6. FHA experiments at an elevated temperature $\left(50^{\circ} \mathrm{C}\right)$ and constant $\left[\mathrm{HNO}_{3}\right]$ with varying FHA.

7. FHA experiments in $1 \mathrm{M} \mathrm{HNO}_{3}$ at varying temperatures $\left(5-65^{\circ} \mathrm{C}\right)$.

8. FHA experiments with HAN initially present in the reacting solution $\left(40^{\circ} \mathrm{C}\right)$.

9. A series of 4 FHA experiments in which the FHA concentration was followed using the colorimetric sampling method described previously rather than the $\mathrm{Pu}(\mathrm{III}) \mathrm{ab}-$ sorbance (experimental conditions as in Fig. 5).

\subsection{Electrochemistry}

Three stock solutions were prepared containing $5 \mathrm{M} \mathrm{HNO}_{3}$, $0.1 \mathrm{M}$ AHA and $0.01 \mathrm{M} \mathrm{Pu}(\mathrm{IV})$, respectively. These were then used to prepare $25 \mathrm{~mL}$ aliquots of solutions containing $\mathrm{Pu}(\mathrm{IV})$ for the electrochemical studies. Each of these solutions contained $0.001 \mathrm{M} \mathrm{Pu}(\mathrm{IV})$ but had varying acidity and AHA : $\mathrm{Pu}$ ratios between $1: 2-20: 1$ ([AHA] = 0.0005-0.02 M; $\left.\left[\mathrm{HNO}_{3}\right]=0.1-3.5 \mathrm{M}\right)$. A Pu only sample at $0.1 \mathrm{M} \mathrm{HNO}_{3}$ was also prepared.

Compared to the $c a .1 \mathrm{~g} / \mathrm{L}$ concentrations more typical of Purex process solutions, $0.001 \mathrm{M} \mathrm{Pu}(\mathrm{IV})(0.24 \mathrm{~g} / \mathrm{L})$ solutions were used for the electrochemical measurements to give lower current densities. The electrochemistry of the solutions was investigated by cyclic voltammetry $(\mathrm{CV})$ using an EG\&G Princeton Applied Research (PAR) Potentiostat/ Galvanostat model 263A and a PAR three electrode cell incorporating an $\mathrm{Ag} / \mathrm{AgCl}$ reference electrode (SSCE) and a Pt auxilliary electrode. Vitreous carbon and Pt disc working electrodes were used for the measurements although the carbon electrode generally showed less well defined waves than the Pt electrode. However, on carbon the accessible potential range extended to $-0.8 \mathrm{~V}$ vs. SSCE whereas on $\mathrm{Pt}$ reductive solvent breakdown occurred at $-0.2 \mathrm{~V} v s$. SSCE. The electrochemical cell was fitted with an argon supply to allow solutions to be purged with Ar and maintained under an Ar atmosphere while measurements were made. Aliquots of $\mathrm{K}_{3}\left[\mathrm{Fe}(\mathrm{CN})_{6}\right]$ solution were added at the end of the measurements to provide an internal reference, noting that the potential of the $\left[\mathrm{Fe}(\mathrm{CN})_{6}\right]^{3-/ 4-}$ couple is dependent on the nature of the supporting electrolyte, including its ionic strength and $\mathrm{pH}[21]$.

The waves in the cyclic voltammograms were described by:

i) the peak anodic and cathodic currents measured by the potentiostat with respect to the horizontal potential/ $x$-axis, $i_{\mathrm{pa}}$ and $i_{\mathrm{pc}}$ respectively,

ii) the peak anodic and cathodic currents within the cyclic voltammogram i.e. the height of the peaks above their prevailing background currents, $i_{\mathrm{da}}$ and $i_{\mathrm{dc}}$ respectively; and

iii) the corresponding peak potentials $E_{\mathrm{pa}}$ and $E_{\mathrm{pc}}$ respectively.

No compensation for internal cell resistance, $R$, was applied during the measurement but plots of $\left(E_{\mathrm{pa}}-E_{\mathrm{pc}}\right), \Delta E_{\mathrm{p}}$, against $\left(i_{\mathrm{pa}}-i_{\mathrm{pc}}\right), \Delta i_{\mathrm{p}}$, or plots of $E_{\mathrm{pa}}$ against $i_{\mathrm{pa}}$ were used to estimate $R$ so that a correction for $i R$ drop could be applied where necessary. Although the values of the peak potentials can be significantly affected by uncompensated cell resistance, the formal electrode potential, $E_{\mathrm{f}}$ given by $\left(E_{\mathrm{pa}}+\right.$ $\left.E_{\mathrm{pc}}\right) / 2$ for reversible/Nernstian systems, is usually much less sensitive. In the examples studied here uncompensated cell resistance might typically result in an overestimate of $E_{\mathrm{f}}$ by between 1 and $5 \mathrm{mV}$. To monitor Pu oxidation state, electronic absorption spectra (EAS) of the solutions were measured over the wavelength range 350-900 nm using a Perkin 
Elmer Lambda 900 spectrophotometer connected via fibre optics to the glovebox.

\section{Results and discussion}

\subsection{XHA hydrolysis}

Hydroxamic acid hydrolysis produces hydroxylamine and the parent carboxylic acid. It is an acid catalysed reaction and in acid solutions the hydroxylamine formed becomes protonated (Eq. (1)) [22]. This instability is a key feature of XHA chemistry that must be accounted for in any process flowsheet design [9]. Conversely, it is actually beneficial in the downstream decomposition of the ligand after separation. It is also fundamental in understanding XHA redox and complexation chemistry.

$$
\mathrm{RCONHOH}+\mathrm{H}_{2} \mathrm{O}+\mathrm{H}^{+} \rightarrow \mathrm{RCOOH}+\mathrm{NH}_{3} \mathrm{OH}^{+}
$$

Miles and Temple [13] had previously shown that FHA hydrolysis was a $2^{\text {nd }}$ order reaction overall, $1^{\text {st }}$ order with respect to both FHA and $\mathrm{HNO}_{3}$. Our data confirmed this, with all experiments for both FHA and AHA conforming to Eq. (2), where $a_{0}=[\mathrm{FHA}]_{0}, b_{0}=\left[\mathrm{HNO}_{3}\right]$ and $x=[\mathrm{FHA}]_{0}-$ $[\mathrm{FHA}]_{\mathrm{t}}[16]$. Results are given in Tables $1-2$ for both FHA and AHA.

$$
\frac{1}{a_{0}-b_{0}} \ln \left(\frac{b_{0}\left(a_{0}-x\right)}{a_{0}\left(b_{0}-x\right)}\right)=k t
$$

The hydrolysis equation (Eq. (3)) was, therefore, determined for both FHA and AHA where rate constants at $25.0{ }^{\circ} \mathrm{C}$ are $0.016 \pm 0.001 \mathrm{dm}^{3} \mathrm{~mol}^{-1} \mathrm{~min}^{-1}$ for FHA and $0.00205 \mathrm{dm}^{3} \mathrm{~mol}^{-1} \mathrm{~min}^{-1}$ for AHA and activation energies were found to be $77.3 \pm 1.6 \mathrm{~kJ} \mathrm{~mol}^{-1}$ (FHA) and $79.9 \pm 2.9 \mathrm{~kJ} \mathrm{~mol}^{-1}$ (AHA) [19]. ${ }^{1}$ The value for AHA is close to that reported by Mane and Jagdale in $\mathrm{HCl}$ [24] $\left(82.4 \mathrm{~kJ} \mathrm{~mol}^{-1}\right)$. Note that this equation is only valid up to $3 \mathrm{M} \mathrm{HNO}_{3}$ as it is well known that at higher acidities a maximum rate is reached. For a more detailed review of the kinetics and mechanisms of the acid catalysed hydrolysis of hydroxamic acids, the interested reader is referred to Ref. [22] and references therein.

$$
-\frac{\mathrm{d}[\mathrm{XHA}]}{\mathrm{d} t}=k[\mathrm{XHA}]\left[\mathrm{H}^{+}\right]
$$

Little variation in the rate constants for AHA or FHA hydrolysis was found on introducing either nitrate (as $\mathrm{NaNO}_{3}$ ) or uranyl nitrate in to the solution (Table 2), although the nitrate data for FHA showed a weak dependency $\left(\propto\left[\mathrm{NO}_{3}{ }^{-}\right]^{\sim 0.2}\right)$. This appears to be consistent with previous studies that showed a positive ionic strength effect. See, for instance, the data of Mane and Jagdale [23, 24] where AHA and hexanohydroxamic acid hydrolysis rates at constant acidity show a chloride dependency of

\footnotetext{
${ }^{1}$ More accurately, the order with respect to acidity in the AHA case was actually 0.9 . This is consistent with apparent orders with respect to $\left[\mathrm{H}^{+}\right]$calculated from the data of Mane and Jagdale between 0-3.0 M acid concentrations for: hexanohydroxamic acid [23] in $\mathrm{HCl}$ and $\mathrm{H}_{2} \mathrm{SO}_{4}$, isobutyrohydroxamic acid in $\mathrm{HCl}$ and $\mathrm{H}_{2} \mathrm{SO}_{4}$ [14] and aceto-, isobutyl- and hexyl- hydroxamic acids in $\mathrm{H}_{2} \mathrm{SO}_{4}$ [24].
}

Table 1. Kinetic analyses of free AHA and FHA hydrolysis rates $([\mathrm{XHA}]=0.05 \mathrm{M})$.

\begin{tabular}{lccl}
\hline & Acidity $(\mathrm{M})$ & Temperature $\left({ }^{\circ} \mathrm{C}\right)$ & Rate constant $\left(\mathrm{min}^{-1}\right)$ \\
\hline AHA & 0.5 & 50 & 0.0157 \\
AHA & 1 & 50 & 0.0245 \\
AHA & 1.5 & 50 & 0.0334 \\
AHA & 2 & 50 & 0.06 \\
AHA & 2 & 50 & 0.0516 \\
AHA & 3 & 50 & 0.0391 \\
AHA & 3 & 50 & 0.0721 \\
AHA & 3 & 50 & 0.0735 \\
AHA & 1 & 58 & 0.04807 \\
AHA & 1 & 56.2 & 0.03689 \\
AHA & 1 & 50.2 & 0.02541 \\
AHA & 1 & 46.8 & 0.01885 \\
AHA & 1 & 41.2 & 0.00977 \\
AHA & 1 & 37.6 & 0.00615 \\
AHA & 1 & 34.7 & 0.00435 \\
AHA & 1 & 31 & 0.00411 \\
AHA & 1 & 28.4 & 0.00243 \\
AHA & 1 & 25 & 0.00211 \\
FHA & 1 & 25 & 0.000267 \\
FHA & 1 & 25.3 & 0.00025 \\
FHA & 1 & 30.4 & 0.00042 \\
FHA & 1 & 35.3 & 0.00075 \\
FHA & 1 & 40.2 & 0.00115 \\
FHA & 1 & 45 & 0.00186 \\
FHA & 1 & 49.7 & 0.00316 \\
FHA & 1 & 55.6 & 0.00455 \\
FHA & 1 & 59.6 & 0.00605 \\
\hline
\end{tabular}

a: Miles and Temple [13].

ca. $0.1-0.2$. Even less variation on the rate with added nitrate ions was observed in the AHA case. For all cases between 1 and $7 \mathrm{M}$ total nitrate the observed AHA hydrolysis closely followed the calculated curves for Eq. (3) with the pseudo-1st order rate constant only increasing from $1.67 \times 10^{-5}$ to $1.73 \times 10^{-5} \mathrm{dm}^{3} \mathrm{~mol}^{-1} \mathrm{~s}^{-1}$ across this range at $20^{\circ} \mathrm{C}$ (Table 2 ). These findings differ from the conclusions drawn by Karraker [25], who observed a substantially decreased AHA half-life on introducing both $\mathrm{NaNO}_{3}$ and uranyl nitrate.

\subsection{Plutonium(IV) reduction by simple hydroxamic acids}

\subsubsection{Experimental results}

It has previously been observed that in the presence of aceto- and formo-hydroxamic acids in nitric acid, dark red $\mathrm{Pu}(\mathrm{IV})$-hydroxamate complexes are gradually reduced to blue $\mathrm{Pu}$ (III) aquo-ions, with the corresponding changes in the absorption spectra confirming such reduction [19]. In order to more fully understand the hydroxamate chemistry of $\mathrm{Pu}$ and to design robust separation process flowsheets, we needed to better understand these reactions. It should be noted that the data gathered during this exercise was mainly under conditions relevant to the broad envelope of flowsheet operations rather than being ideally suited to kinetic analysis. This has complicated subsequent data interpretation, particularly at high [XHA]. At the high XHA (particularly FHA) concentrations used in some of these experiments, we note that it seems likely that activity effects will become 
Table 2. Comparison of experimentally determined and calculated rate constants for FHA and AHA hydrolysis with variable total nitrate and uranyl nitrate concentrations.

\begin{tabular}{lccccccc}
\hline $\begin{array}{l}{[\mathrm{XHA}]_{0}} \\
(\mathrm{M})\end{array}$ & $\mathrm{X}$ & $\begin{array}{c}{\left[\mathrm{NO}_{3}{ }^{-}\right]} \\
(\mathrm{M})\end{array}$ & $\begin{array}{c}{[\mathrm{U}(\mathrm{VI})]} \\
(\mathrm{M})\end{array}$ & $\begin{array}{c}{\left[\mathrm{H}^{+}\right]} \\
(\mathrm{M})\end{array}$ & $\begin{array}{c}T \\
\left({ }^{\circ} \mathrm{C}\right)\end{array}$ & $\begin{array}{c}k_{\text {(calc) }} \\
\left(\mathrm{dm}^{3} \mathrm{~mol}^{-1} \mathrm{~s}^{-1}\right)\end{array}$ & $\begin{array}{c}k_{\text {(expt) }} \\
\left(\mathrm{dm}^{3} \mathrm{~mol}^{-1} \mathrm{~s}^{-1}\right)\end{array}$ \\
\hline 0.04 & $\mathrm{~F}$ & 1.6 & 0 & 0.8 & 40 & 0.00113 & 0.00106 \\
0.0333 & $\mathrm{~F}$ & 2 & 0 & 0.67 & 40.3 & 0.00117 & 0.00122 \\
0.0286 & $\mathrm{~F}$ & 2.86 & 0 & 1.14 & 40 & 0.00113 & 0.00117 \\
0.0125 & $\mathrm{~F}$ & 3.5 & 0 & 1 & 40 & 0.00113 & 0.00134 \\
0.0333 & $\mathrm{~F}$ & 1.00 & 0.165 & 0.67 & 24 & 0.00023 & 0.00018 \\
0.0242 & $\mathrm{~F}$ & 2.27 & 0.126 & 2.02 & 21.1 & 0.00017 & 0.00019 \\
0.0395 & $\mathrm{~F}$ & 1.81 & 0.099 & 1.61 & 21.1 & 0.00017 & 0.00018 \\
0.00512 & $\mathrm{~A}$ & 1.00 & 0 & 1.00 & 20 & $1.84 \times 10^{-5}$ & $1.67 \times 10^{-5}$ \\
0.00487 & $\mathrm{~A}$ & 1.99 & 0 & 1.00 & 20 & $1.84 \times 10^{-5}$ & $1.66 \times 10^{-5}$ \\
0.00490 & $\mathrm{~A}$ & 3.00 & 0 & 1.00 & 20 & $1.84 \times 10^{-5}$ & $1.67 \times 10^{-5}$ \\
0.00487 & $\mathrm{~A}$ & 4.00 & 0 & 1.00 & 20 & $1.84 \times 10^{-5}$ & $1.68 \times 10^{-5}$ \\
0.00485 & $\mathrm{~A}$ & 5.04 & 0 & 1.00 & 20 & $1.84 \times 10^{-5}$ & $1.72 \times 10^{-5}$ \\
0.00502 & $\mathrm{~A}$ & 6.00 & 0 & 1.00 & 20 & $1.84 \times 10^{-5}$ & $1.70 \times 10^{-5}$ \\
0.00485 & $\mathrm{~A}$ & 6.99 & 0 & 1.00 & 20 & $1.84 \times 10^{-5}$ & $1.73 \times 10^{-5}$ \\
\hline
\end{tabular}

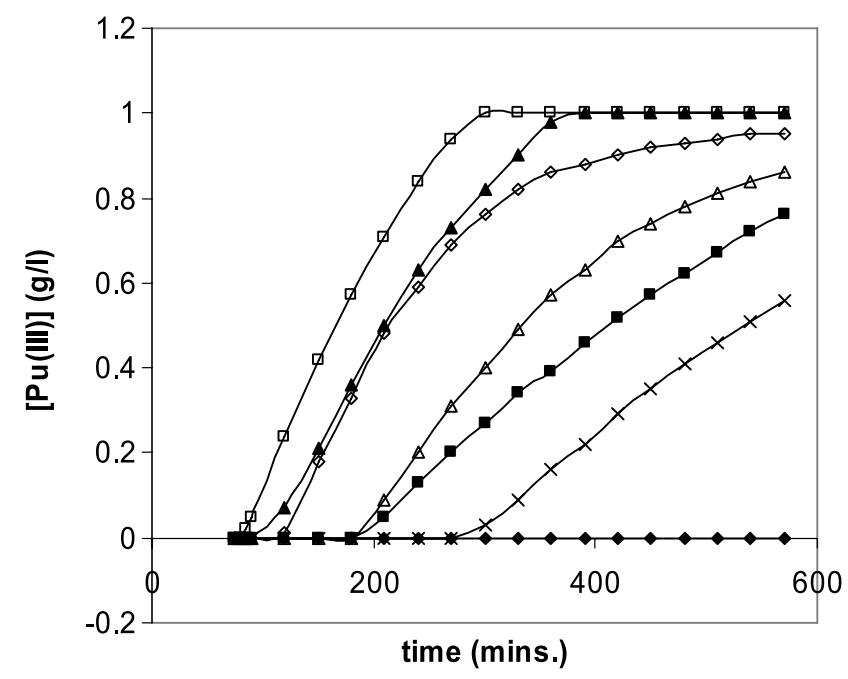

increasingly important, causing deviations from simple behaviours expected on a concentration basis.

The reduction is characterised by a variable induction period followed by an apparent near zero-order growth in $\mathrm{Pu}$ (III) concentration, measured from the $\mathrm{Pu}$ (III) absorption peak at $\sim 908 \mathrm{~nm}$ (example data for FHA at varying nitric acid concentrations is shown in Fig. 1). The length of this induction period is reduced with increases in acidity or temperature and decreases in FHA concentration. The addition of uranyl or nitrate $\left(\mathrm{NaNO}_{3}\right)$ ions had little discernible effect on the induction periods in the FHA system but induction periods did appear to decrease in the AHA system. Interestingly, in the experiment (coded "P3X41") where initially the concentration of FHA exceeded the nitric acid concentration $\left(\left[\mathrm{HNO}_{3}\right]=0.5 \mathrm{M} ;[\mathrm{Pu}(\mathrm{IV})]_{0}=1 \mathrm{~g} / \mathrm{L} ;[\right.$ FHA $]=1 \mathrm{M}$; $T=20^{\circ} \mathrm{C}$; filled diamond data points in Fig. 1), no reaction was observed over the duration of monitoring (> $570 \mathrm{~min})$. This is not a simple acidity effect as in another experiment at $0.32 \mathrm{M} \mathrm{HNO}_{3}$ reduction was observed. It appears to be related to the $[\mathrm{FHA}]:\left[\mathrm{HNO}_{3}\right]$ ratio. The induction period in these reduction reactions is most certainly related to the hydrolysis of the hydroxamic acid. As the excess (free, unbound) hydroxamic acid in the bulk solution is hydrolysed to hydroxylamine and the carboxylic acid (via Eq. (1)),

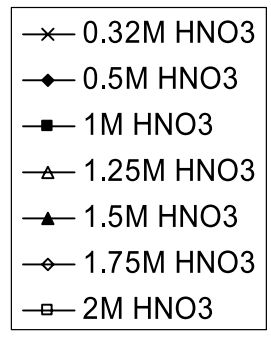

Fig. 1. Growth of $\mathrm{Pu}(\mathrm{III})$ from the reduction of $\mathrm{Pu}(\mathrm{IV})\left(1 \mathrm{~g} / \mathrm{L} ; T=20^{\circ} \mathrm{C}\right)$ by $1 \mathrm{M}$ FHA in 0.5-2 $\mathrm{M} \mathrm{HNO}_{3}$. Also shown is an additional experiment at $0.32 \mathrm{M} \mathrm{HNO}_{3}$ with $0.3 \mathrm{M} \mathrm{FHA}$, i.e. $[\mathrm{FHA}] \leq\left[\mathrm{HNO}_{3}\right]$.

the $\mathrm{Pu}(\mathrm{IV})$ speciation changes and, when some threshold is passed, de-complexed $\mathrm{Pu}(\mathrm{IV})$ becomes available for reduction (Eq. (4)). This was supported by later experiments (P5X1-4), where the ratios of $\mathrm{Pu}(\mathrm{IV})$ and AHA concentrations were varied between $3.5: 1-1: 2$, and which showed very low inductions periods of a few minutes only.

$$
\begin{aligned}
& \mathrm{Pu}_{\mathrm{aq}}^{4+}+n \mathrm{XHA} \stackrel{\text { fast }}{\longleftrightarrow} \mathrm{Pu}(\mathrm{XHA})_{n}{ }^{4-n} \stackrel{\mathrm{H}^{+}, \text {slow }}{\longleftrightarrow} \mathrm{Pu}(\mathrm{IV}) \\
& +\mathrm{XHA}+\mathrm{NH}_{3} \mathrm{OH}^{+}+\mathrm{XCOOH} \stackrel{\mathrm{XHA} / \mathrm{NH}_{3} \mathrm{OH}^{+}, \text {fast }}{\longrightarrow} \mathrm{Pu}_{\mathrm{aq}}^{3+}
\end{aligned}
$$

Other qualitative comparisons can be made between the FHA and AHA data. Pu(IV) reduction is broadly similar for both cases as might be expected (Fig. 2), although the AHA reaction is markedly slower probably reflecting the greater stability of AHA compared with FHA towards hydrolysis. In some cases (at $40^{\circ} \mathrm{C}$ ) the reduction appeared to stop before completion with even some re-oxidation of $\mathrm{Pu}$ (III) back to $\mathrm{Pu}(\mathrm{IV})$ (e.g. Fig. 2 curve P3X23). Similarly, in experiments where $[\mathrm{AHA}]<[\mathrm{Pu}(\mathrm{IV})]$ re-oxidation of $\mathrm{Pu}(\mathrm{III})$ back to $\mathrm{Pu}(\mathrm{IV}$ ) occurs (see Fig. 3). Whilst we were unable to directly measure any absorbance due to $\mathrm{HNO}_{2}$ due to the $\mathrm{Pu}(\mathrm{IV})$-AHA bands below $500 \mathrm{~nm}$, it is well known that $\mathrm{Pu}(\mathrm{III})$ oxidation in nitric acid is autocatalysed by nitrous 


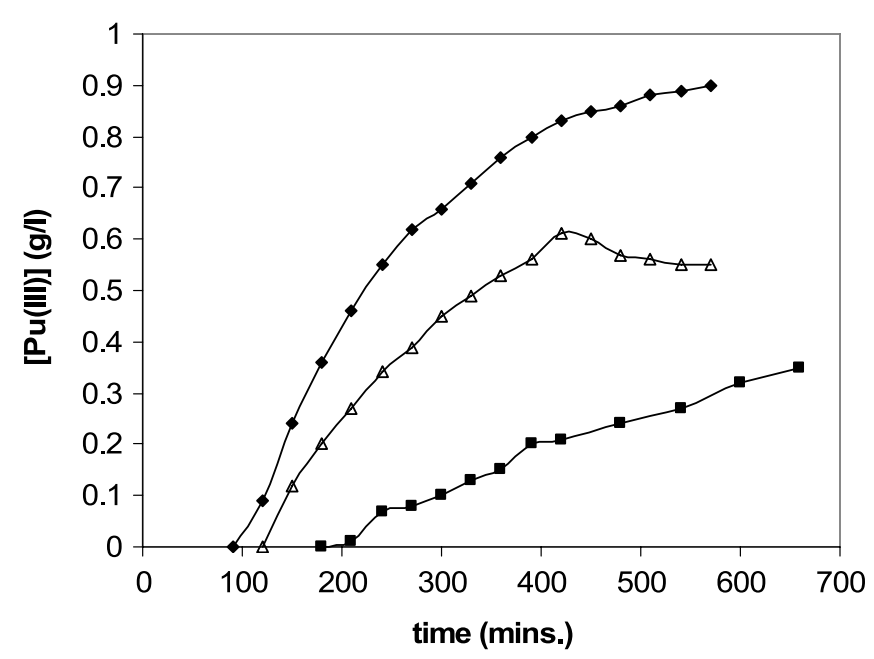

$\rightarrow \mathrm{FHA} \rightarrow-\mathrm{AHA} \triangle \mathrm{P} 3 \mathrm{X} 23$

Fig. 2. Comparison of $0.1 \mathrm{M}$ AHA and FHA reductions of $1 \mathrm{~g} / \mathrm{L}$ $\mathrm{Pu}(\mathrm{IV})$ in $1 \mathrm{M} \mathrm{HNO}_{3}\left(T=20^{\circ} \mathrm{C}\right)$. Also shown is experiment $\mathrm{P} 3 \mathrm{X} 23$ where some re-oxidation of $\mathrm{Pu}(\mathrm{III})$ is observed at long times $([\mathrm{Pu}]=$ $\left.1 \mathrm{~g} / \mathrm{L} ;\left[\mathrm{HNO}_{3}\right]=2 \mathrm{M} ;[\mathrm{AHA}]=0.1 \mathrm{M} ; T=40^{\circ} \mathrm{C}\right)$.

acid that accumulates in the solution as a product of the reaction. $\mathrm{Pu}(\mathrm{III})$ can only be stabilised in $\mathrm{HNO}_{3}$ by interrupting this cycle of reactions using a reagent, such as hydrazine, that reacts rapidly with nitrous acid [26]. Hydroxylamine and hydroxamic acids also 'scavenge' nitrous acid in this fashion so presumably visible $\mathrm{Pu}(\mathrm{III})$ re-oxidation only occurs at the point at which both AHA and hydroxylamine are removed from the solution and are no longer available to scavenge nitrous acid (Fig. 3). Temperature had a major effect on reduction of $\mathrm{Pu}(\mathrm{IV})$ by both FHA and AHA as illustrated in Fig. 4 which shows the FHA-Pu(IV) data between 5 and $30^{\circ} \mathrm{C}$. At higher temperatures the reaction is completed at even quicker timescales, with the induction period completely disappearing around $50{ }^{\circ} \mathrm{C}$ (data not shown). This is most probably a combination of effects due to the increased rates of XHA hydrolysis and $\mathrm{Pu}(\mathrm{IV})$ reduction at higher temperatures and the increased generation of $\mathrm{HNO}_{2}$. Clearly, further specific experiments are needed to clarify the role that $\mathrm{HNO}_{2}$ has, in particular at elevated temperatures and on the later stages of the reaction.

Fig. 5 illustrates experiments P4X19-22 in which the FHA concentration rather than the $\mathrm{Pu}(\mathrm{III})$ was followed (by sampling and using the off-line colorimetric method). It is clear that the decreases in FHA concentrations in the two experiments, in the absence and presence of $\mathrm{Pu}(\mathrm{IV})$ with $1 \mathrm{M} \mathrm{FHA}$ in $1 \mathrm{M} \mathrm{HNO}_{3}$, are essentially the same, i.e. the presence of $1 \mathrm{~g} / \mathrm{L} \mathrm{Pu}(\mathrm{IV})$ has no effect on bulk (free) FHA loss through acid hydrolysis. Also, when FHA is in excess of the $\mathrm{HNO}_{3}$ (i.e. $1 \mathrm{M} \mathrm{FHA} ; 0.5 \mathrm{M} \mathrm{HNO}_{3}$ ) in run $\mathrm{P} 4 \mathrm{X} 21$, the FHA hydrolysis reaches a steady state with $0.5 \mathrm{M}$ FHA
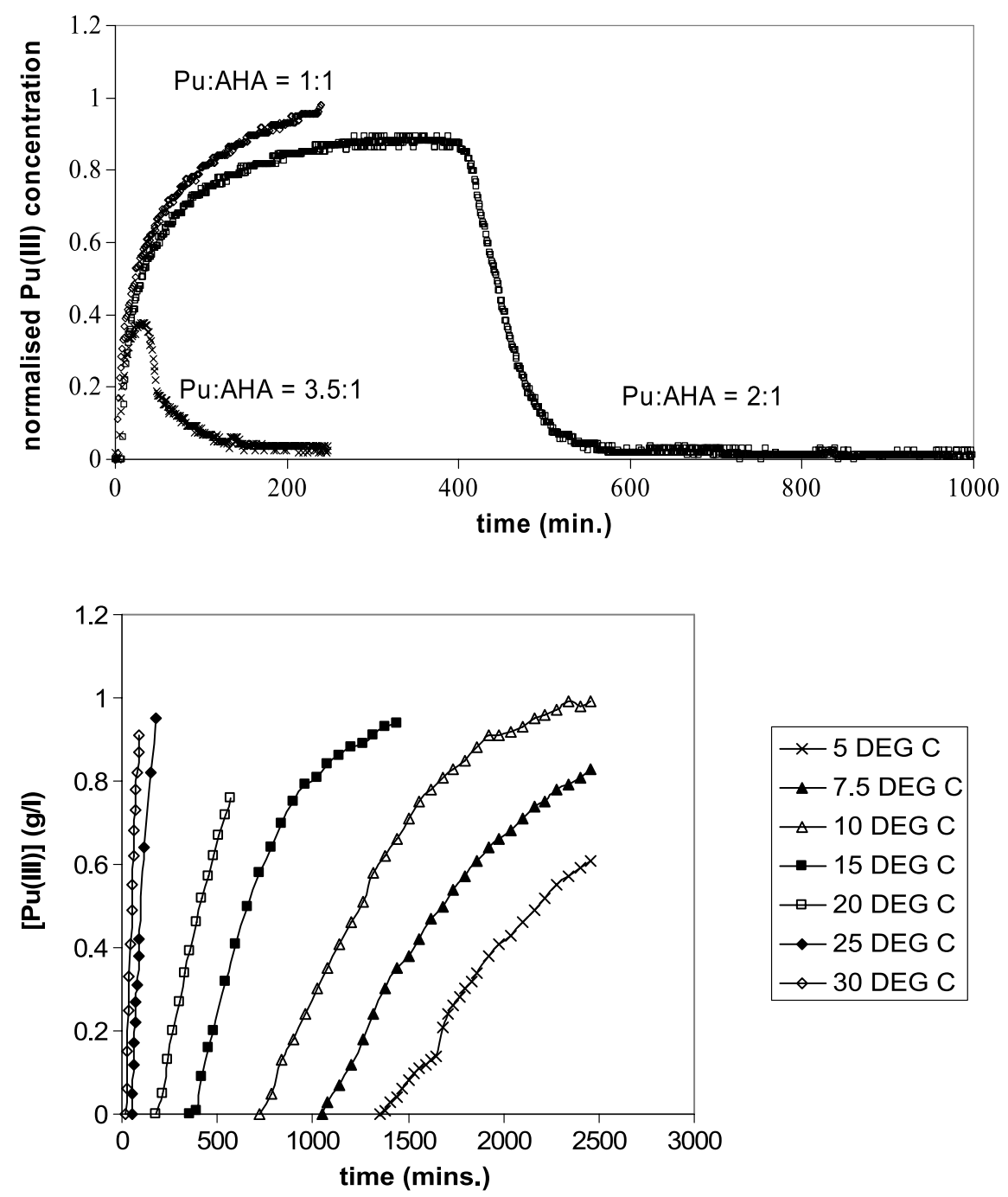

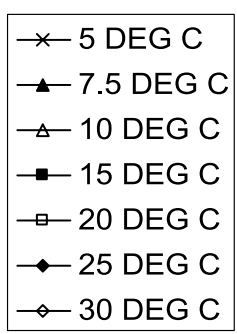

Fig. 3. $\mathrm{Pu}(\mathrm{IV})-\mathrm{AHA}$ reduction at low molar AHA : $\mathrm{Pu}$ ratios $\left([\mathrm{Pu}]=1 \mathrm{~g} / \mathrm{L} ;\left[\mathrm{HNO}_{3}\right]=\right.$ $\left.1 \mathrm{M} ;[\mathrm{AHA}]=0.0042-0.001 \mathrm{M} ; T=25^{\circ} \mathrm{C}\right)$.
Fig. 4. Temperature dependence $\left(5-30^{\circ} \mathrm{C}\right)$ of the $\mathrm{Pu}(\mathrm{IV})-\mathrm{FHA}$ reaction $([\mathrm{Pu}]=1 \mathrm{~g} / \mathrm{L} ;[\mathrm{FHA}]=$ $\left.1 \mathrm{M} ;\left[\mathrm{HNO}_{3}\right]=1 \mathrm{M}\right)$. 


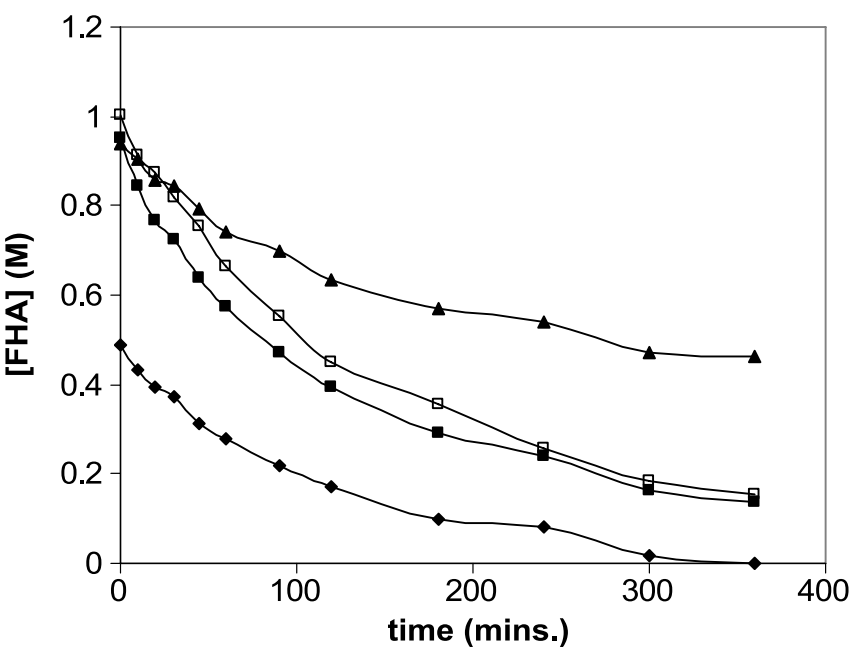

remaining. This is presumably due to protonation of the hydroxylamine product causing a depletion of free acidity in the solution to the point where the FHA acid catalysed hydrolysis slows to negligible levels (i.e. see Eq. (1)). In the reverse situation where $\left[\mathrm{HNO}_{3}\right]:[\mathrm{FHA}]=2: 1$, the hydrolysis proceeds normally to completion (P4X19). Finally, the similarity of all the FHA hydrolysis rate constants for experiments P4X19-21,23 suggests a reasonable selfconsistency is attained in these experiments, although the actual mean value of $2.14 \times 10^{-4} \mathrm{dm}^{3} \mathrm{~mol}^{-1} \mathrm{~s}^{-1}$ is somewhat higher than the value calculated using the accepted kinetics, see Sect. $3.1\left(1.51 \times 10^{-4} \mathrm{dm}^{3} \mathrm{~mol}^{-1} \mathrm{~s}^{-1}\right)$. These observations explain the lack of $\mathrm{Pu}(\mathrm{IV})$ reduction observed in $\mathrm{P} 3 \mathrm{X} 41$ when $[\mathrm{XHA}]>\left[\mathrm{HNO}_{3}\right]$, as the 'switching off' of the hydrolysis reaction means sufficient XHA always remains in solution to complex the $\mathrm{Pu}(\mathrm{IV})$ and the threshold at which de-complexed $\mathrm{Pu}(\mathrm{IV})$ becomes available for reduction is not reached.

The addition of up to $1 \mathrm{M}$ hydroxylamine nitrate (HAN) solutions to the initial reaction mixture had little discernible effects (Fig. 6); this appears to agree with an observation made by Karraker [25]. It should be noted that Barney's

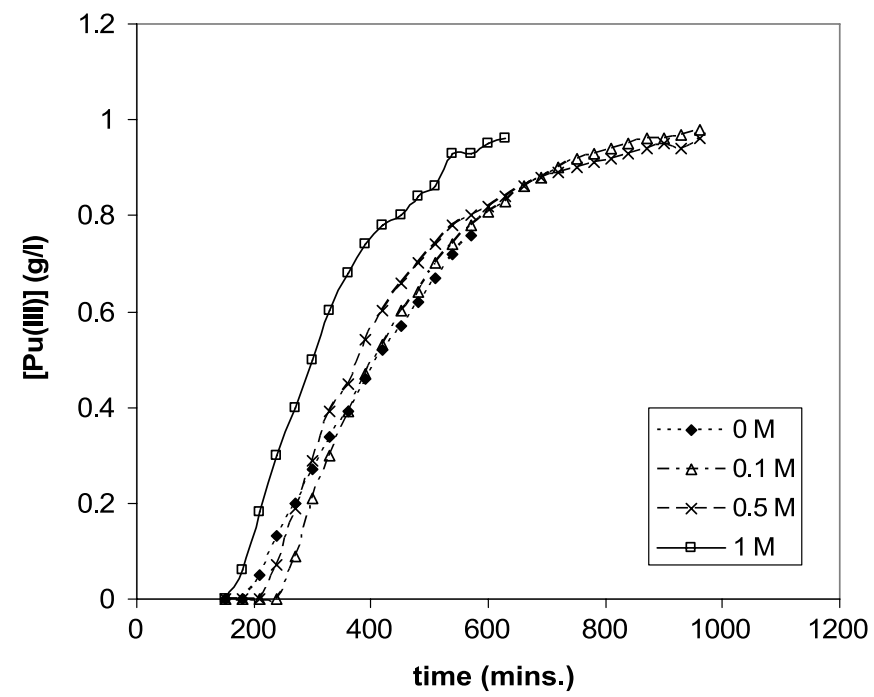

Fig. 6. Effect of adding 0-1 $\mathrm{M}$ hydroxylamine nitrate to the $\mathrm{Pu}(\mathrm{IV})-$ FHA reaction $\left([\mathrm{Pu}]=1 \mathrm{~g} / \mathrm{L} ;\left[\mathrm{HNO}_{3}\right]=1 \mathrm{M} ;[\mathrm{FHA}]=1 \mathrm{M} ; T=\right.$ $\left.20^{\circ} \mathrm{C}\right)$.

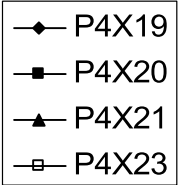

Fig. 5. The hydrolysis of $\mathrm{FHA}$ in $\mathrm{HNO}_{3}$ at $20^{\circ} \mathrm{C}$. Where: $\mathrm{P} 4 \mathrm{X} 19,[\mathrm{Pu}(\mathrm{IV})]=0 \mathrm{~g} / \mathrm{L} ;\left[\mathrm{HNO}_{3}\right]=$ $1 \mathrm{M}$; $[\mathrm{FHA}]=0.5 \mathrm{M} . \mathrm{P} 4 X 20,[\mathrm{Pu}(\mathrm{IV})]=0 \mathrm{~g} / \mathrm{L}$; $\left[\mathrm{HNO}_{3}\right]=1 \mathrm{M}$; [FHA] = 1 M. P4X21, [Pu(IV)] $1 \mathrm{~g} / \mathrm{L} ;\left[\mathrm{HNO}_{3}\right]=0.5 \mathrm{M} ;[\mathrm{FHA}]=1 \mathrm{M} . \mathrm{P} 4 \mathrm{X} 23$, $[\mathrm{Pu}(\mathrm{IV})]=1 \mathrm{~g} / \mathrm{L} ;\left[\mathrm{HNO}_{3}\right]=1 \mathrm{M} ;[\mathrm{FHA}]=1 \mathrm{M}$.

$\mathrm{Pu}(\mathrm{IV})-\mathrm{HAN}$ kinetics [20] could not be fitted to these runs with HAN added. So these experiments with HAN added to the $\mathrm{Pu}(\mathrm{IV})$-AHA system appeared to suggest that not only is HAN probably not the reductant for $\mathrm{Pu}(\mathrm{IV})$ in this system but also in the presence of XHA it is actually prevented from reducing $\mathrm{Pu}(\mathrm{IV})$. It should be noted however that the HAN : $\mathrm{Pu}(\mathrm{IV})$ ratios probably present in this system at the end of the induction period are much higher than those studied by Barney [20].

One other interesting observation made by Karraker [25] was that AHA added to $\mathrm{Pu}(\mathrm{III})$ causes formation of the $\mathrm{Pu}(\mathrm{IV})$-AHA complex, but this apparent oxidising ability of AHA is difficult to rationalise. We, therefore, spectroscopically followed three different solutions with initial $\mathrm{Pu}$ (III) concentrations of $0.2,0.5,1.0 \mathrm{~g} / \mathrm{L}$ (no $\mathrm{Pu}(\mathrm{IV})$ present) at an AHA concentration of $0.1 \mathrm{M}\left(\left[\mathrm{HNO}_{3}\right]=1 \mathrm{M} ; T=25^{\circ} \mathrm{C}\right)$. No reaction was observed with $\mathrm{Pu}(\mathrm{III})$ being stable for time periods of over $200 \mathrm{~min}$. Similar experiments in the presence of $1 \mathrm{~g} / \mathrm{L} \mathrm{Pu}(\mathrm{IV})$ were difficult to analyse due to spectral interferences but again there was little real evidence for any oxidation of $\mathrm{Pu}(\mathrm{III})$. Fig. 3 shows $\mathrm{Pu}(\mathrm{III})$ re-oxidation can occur once the AHA and HAN are fully oxidized and no longer available in solution to scavenge $\mathrm{HNO}_{2}$.

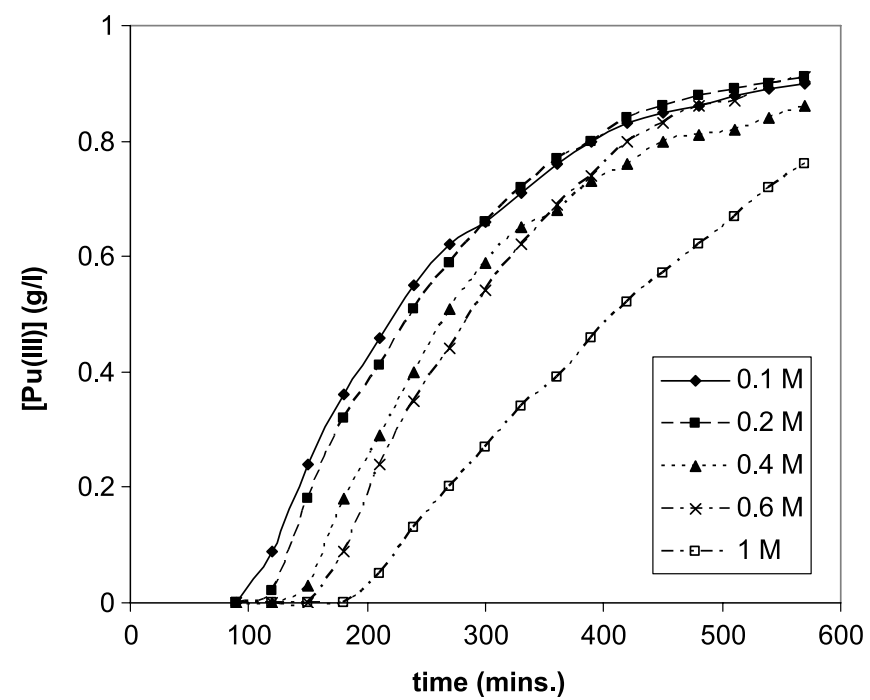

Fig. 7. Effect of variable FHA concentration $(0.1-1.0 \mathrm{M})$ on the reduction of $1 \mathrm{~g} / \mathrm{L} \mathrm{Pu}(\mathrm{IV})$ by $\mathrm{FHA}$ at $20^{\circ} \mathrm{C}\left(\left[\mathrm{HNO}_{3}\right]=1 \mathrm{M}\right)$. 


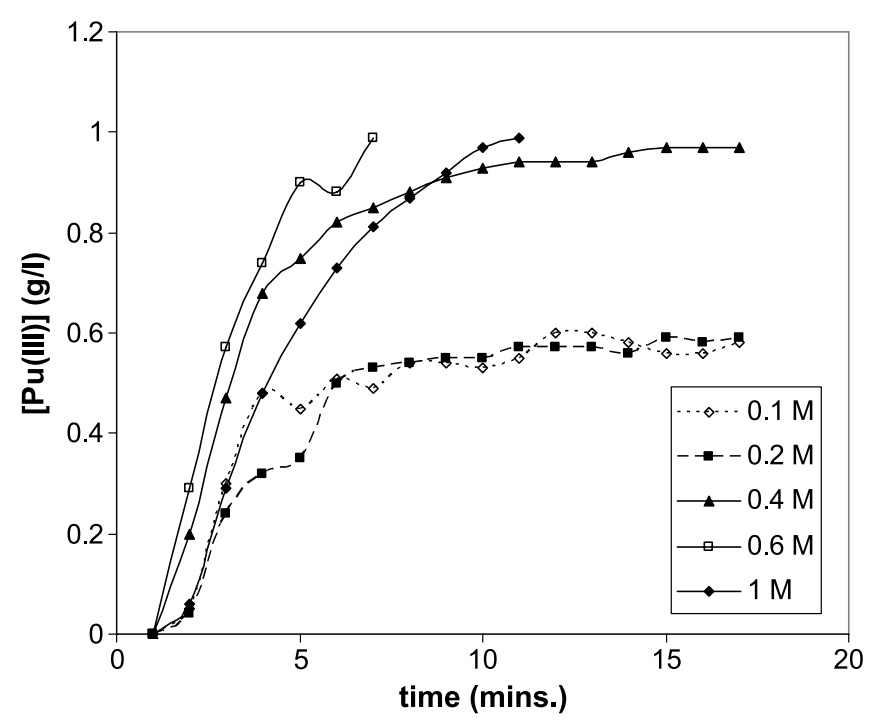

Fig. 8. Effect of variable FHA concentration $(0.1-1.0 \mathrm{M})$ on the reduction of $1 \mathrm{~g} / \mathrm{L} \mathrm{Pu}(\mathrm{IV})$ by $\mathrm{FHA}$ at $50{ }^{\circ} \mathrm{C}\left(\left[\mathrm{HNO}_{3}\right]=1 \mathrm{M}\right)$.

Whilst most of the experimental runs showed a near linear growth in $\mathrm{Pu}(\mathrm{III})$ which could be interpreted as apparent zero-order kinetics, some experiments at longer timescales and at low FHA concentrations showed clear deviations from this trend. Fig. 7 illustrates the experiments at variable FHA concentrations showing such changes in the $\mathrm{Pu}(\mathrm{III})$ growth curves between 0.6 and $1 \mathrm{M}$ FHA. The effects of elevated temperatures on the reduction, described previously, are further illustrated by the set of experiments with variable FHA concentration at $50{ }^{\circ} \mathrm{C}$ (Fig. 8). It is also seen from this figure that at low [FHA] the reduction appears to reach a steady state around $60 \%$ completion, presumably in these runs the reductant(s) quickly became exhausted either through hydrolysis and/or reaction with $\mathrm{HNO}_{2}$ generated insitu. Accordingly, it does seem clear from these data that the rate and extent of $\mathrm{Pu}(\mathrm{IV})$ reduction in the presence of XHA is not amenable to simple kinetic treatments (i.e. zero, $1^{\text {st }}$ or $2^{\text {nd }}$ order kinetics).

\subsubsection{Discussion}

The potential complexity of this system which can involve hydrolysis of free and bound XHA, up to $4 \mathrm{Pu}(\mathrm{IV})-$ AHA complexes, two reducing agents for $\mathrm{Pu}(\mathrm{IV})$ (XHA and $\mathrm{HAN})$ and other ligands $\left(\mathrm{XCOOH}, \mathrm{NO}_{3}{ }^{-}\right)$has been discussed previously [27]. A preliminary analysis of the reaction rates presented therein showed that $\ln -\ln$ plots of the apparent zero order rate constants, determined from the kinetic runs, against $\left[\mathrm{H}^{+}\right]$at the end of the induction period and against $[\mathrm{Pu}(\mathrm{IV})]_{0}$ gave linear plots of gradients $\sim+1.2$ and $\sim+0.8$ respectively, i.e. approximately unity. It was noted that the relationship between reaction rate and FHA concentration was difficult to interpret and that $\mathrm{U}(\mathrm{VI})$ and nitrate ions had little discernible effect on the reaction rates. An Arrhenius plot gave a reasonably linear relationship between $\ln k_{\mathrm{obs}}$ and $1 / T$, indicating an activation energy of $\sim 90 \mathrm{~kJ} \mathrm{~mol}^{-1}$ and a pre-exponential factor of $\sim 2.3 \times 10^{9} \mathrm{~s}^{-1}$. Taylor et al. [27] then calculated reaction half-lives and rate constants for FHA hydrolysis and compared these with experimental values for each kinetic experiment, showing reasonable concordance between hydrolytic and experimental values. It was proposed that this analysis, which was admittedly of a very basic and empirical nature, indicated that the reduction of $\mathrm{Pu}(\mathrm{IV})$ in the presence of a hydroxamic acid was controlled by the rate of hydrolysis of the free hydroxamic acid. This was based on the similarity of the activation energy and pre-exponential factor, reaction half-lives and orders of reaction with respect to $\mathrm{HNO}_{3}$ and initial $\mathrm{Pu}$.

Qualitatively, the experimental data presented here is consistent with a situation in which $\mathrm{Pu}(\mathrm{IV})$ is strongly stabilised as the hydroxamate complex. Excess free hydroxamic acid in the bulk solution is being continually depleted through acid hydrolysis. At some critical point the complex starts to dissociate, releasing a reducible form of $\mathrm{Pu}(\mathrm{IV})$ (most probably the free $\mathrm{Pu}^{4+}\left(\mathrm{PuNO}_{3}{ }^{3+}\right)$ ion). This is represented experimentally by the end of the induction period and the appearance of $\mathrm{Pu}$ (III) in solution as the 'free' $\mathrm{Pu}(\mathrm{IV})$ is rapidly reduced either by the hydroxylamine formed from XHA hydrolysis or the hydroxamic acid itself. A full kinetic analysis of the AHA data has now been completed and will be reported separately [28] but it is sufficient to note here that the detailed treatment is generally consistent with the overall scheme described herein.

\section{3 $\mathrm{Pu}(\mathrm{IV}) / \mathrm{Pu}(\mathrm{III})$ redox potential shifts due to $\mathrm{AHA}$ complexation}

\subsubsection{Cyclic voltammetry}

The previous section described the reduction of $\mathrm{Pu}(\mathrm{IV})$ ions by AHA and FHA. However, the nature of the actual reductant is uncertain in that whilst hydroxamic acids are reducing agents, their hydrolysis product - hydroxylamine - is also well known as a good reductant for $\mathrm{Pu}(\mathrm{IV})$, particularly at low acidities [20, 29, 30]. Stoichiometric equations for HAN and XHA reduction reactions are given in Eqs. (5)-(8), with Eqs. (5) and (7) applying when the reductant (HAN, XHA) is in excess and Eqs. (6) and (8) applying when the oxidant $\left(\mathrm{Pu}^{4+}\right)$ is in excess (n.b. the XHA equations are derived by direct analogy with HAN and accounting for our [12] and Karraker's [25] observations of a 2:1 stoichiometry in the $\mathrm{Ce}(\mathrm{IV})+\mathrm{AHA}$ reduction reaction when cerium is in excess). The presence of an induction period might suggest that HAN is the reductant with reduction starting once HAN reaches a significant level. However, in this case experiments with HAN initially present in solution should have led to an elimination of the induction period. That they did not suggests that $\mathrm{Pu}(\mathrm{IV})$ is stabilised by XHA complexation either due to a consequent shift in the redox potential for $\mathrm{Pu}(\mathrm{IV}) / \mathrm{Pu}(\mathrm{III})$ that then thermodynamically prohibits reaction with XHA and/or HAN or because reduction may be kinetically hindered due to steric effects.

$$
\begin{gathered}
2 \mathrm{Pu}^{4+}+2 \mathrm{NH}_{3} \mathrm{OH}^{+} \Leftrightarrow 2 \mathrm{Pu}^{3+}+2 \mathrm{H}_{2} \mathrm{O}+\mathrm{N}_{2}+4 \mathrm{H}^{+} \\
4 \mathrm{Pu}^{4+}+2 \mathrm{NH}_{3} \mathrm{OH}^{+} \Leftrightarrow 4 \mathrm{Pu}^{3+}+\mathrm{H}_{2} \mathrm{O}+\mathrm{N}_{2} \mathrm{O}+6 \mathrm{H}^{+} \\
2 \mathrm{Pu}^{4+}+2 \mathrm{XCONHOH} \Leftrightarrow \\
2 \mathrm{Pu}^{3+}+2 \mathrm{XCOOH}+\mathrm{N}_{2}+2 \mathrm{H}^{+} \\
4 \mathrm{Pu}^{4+}+2 \mathrm{XCONHOH}+\mathrm{H}_{2} \mathrm{O} \Leftrightarrow \\
4 \mathrm{Pu}^{3+}+2 \mathrm{XCOOH}+\mathrm{N}_{2} \mathrm{O}+4 \mathrm{H}^{+}
\end{gathered}
$$


Table 3. $E_{\mathrm{f}}$ values for solutions of $0.001 \mathrm{M} \mathrm{Pu}^{4+}$ in $0.1 \mathrm{M} \mathrm{HNO}_{3}$ with varying $\mathrm{AHA}$ concentrations.

\begin{tabular}{lcccccccccc}
\hline AHA : Pu ratio & 0 & 0.5 & 1 & 2 & 3 & 4 & 6 & 8 & 10 & 20 \\
\hline $\begin{array}{l}E_{\mathrm{f}} \mathrm{Pu}^{4+/ 3+} \\
(\mathrm{mV} \mathrm{Ag} / \mathrm{AgCl})\end{array}$ & 733 & 731 & 646 & 645 & 625 & 610 & 621 & 603 & 598 & 598 \\
$\begin{array}{l}E_{\mathrm{f}} \mathrm{Fe}^{3+/ 2+} \\
(\mathrm{mV} \mathrm{Ag} / \mathrm{AgCl})\end{array}$ & 400 & & & & 373 & 401 & 440 & 412 & & \\
$\begin{array}{l}E_{\mathrm{f}} \mathrm{Pu}^{4+/ 3+} \\
(\mathrm{mV} \mathrm{adjusted})^{a}\end{array}$ & 733 & & & & 652 & 609 & 581 & 591 & & \\
\hline
\end{tabular}

a: $E_{\mathrm{f}} \mathrm{Pu}^{4+/ 3+}$ adjusted to correspond with an $E_{\mathrm{f}}$ of $400 \mathrm{mV}$ for $\left[\mathrm{Fe}(\mathrm{CN})_{6}\right]^{3-/ 4-}$.

Cyclic voltammetry was used to investigate the shift in the $\mathrm{Pu}(\mathrm{IV}) /(\mathrm{III})$ redox couple in the presence of AHA. In an initial trial experiment the cyclic voltammograms (CVs) of a solution containing $0.001 \mathrm{M} \mathrm{Pu}(\mathrm{IV})$ in $0.1 \mathrm{M} \mathrm{HNO}_{3}$ were recorded using a Pt working electrode at scan rates of 50, 100 and $200 \mathrm{mV} \mathrm{s}^{-1}$. Plots of measured peak currents, $i_{\mathrm{pa}}$ and $i_{\mathrm{pc}}$, against the square root of the scan rate, $v^{1 / 2}$ were linear indicating that the electron transfer was close to diffusion controlled. Peak potentials were invariant with $v$ indicating that the reaction was electrochemically reversible under these conditions. The ratios of the peak currents $i_{\mathrm{da}} / i_{\mathrm{dc}}$ were close to 1 , again indicating that the process was chemically and electrochemically reversible at the scan rates used. After correction for internal cell resistance the value of $E_{\mathrm{f}}$ for the $\mathrm{Pu}^{4+/ 3+}$ couple was found to be $+0.733 \mathrm{~V}$ (vs. SSCE) or $+0.942 \mathrm{~V}$ (vs. NHE). This value lies between the values of +0.885 and $+0.966 \mathrm{~V}$ ( $v s$. NHE) that we have calculated as the standard electrode potentials for the $\mathrm{Pu}\left(\mathrm{NO}_{3}\right)_{2}{ }^{2+} / \mathrm{Pu}^{3+}$ and $\mathrm{Pu}\left(\mathrm{NO}_{3}\right)^{3+} / \mathrm{Pu}^{3+}$ systems, respectively (see Fig. 12, vide infra). This suggests that the $\mathrm{Pu}(\mathrm{IV})$ is present as a mixture of $\mathrm{Pu}\left(\mathrm{NO}_{3}\right)^{3+}$ and $\mathrm{Pu}\left(\mathrm{NO}_{3}\right)_{2}{ }^{2+}$ species under the conditions studied.

Adding $0.1 \mathrm{M}$ AHA solution (AHA : $\mathrm{Pu}=6: 1$ ) and scanning at 50, 100 and $200 \mathrm{mV} \mathrm{s}^{-1}$ (Fig. 9) also gave linear plots of $i_{\mathrm{pa}}$ and $i_{\mathrm{pc}}$ against $v^{1 / 2}$ with a near zero intercept and current ratios $\left(i_{\mathrm{da}} / i_{\mathrm{dc}}\right)$ close to 1 . Peak potentials were again invariant with $v$, suggesting that the system is behaving reversibly under these conditions. After correction for internal cell resistance the value of $E_{\mathrm{f}}$ was found to be $+0.581 \mathrm{~V}$ (vs. SSCE) corresponding to a shift on complexation by acetohydroxamate of $0.152 \mathrm{~V}$ from the value of $E_{\mathrm{f}}$ recorded for the $\mathrm{Pu}^{4+/ 3+}$ couple in $0.1 \mathrm{M} \mathrm{HNO}_{3}$ (Fig. 10). A solution of $\mathrm{K}_{3}\left[\mathrm{Fe}(\mathrm{CN})_{6}\right]$ was added and the value of $E_{\mathrm{f}}$ for the $\left[\mathrm{Fe}(\mathrm{CN})_{6}\right]^{3-/ 4-}$ couple under these conditions was found to be $+0.4 \mathrm{~V}(v s . \mathrm{SSCE})$.

A series of $\mathrm{CVs}$ with $0.001 \mathrm{M} \mathrm{Pu}^{4+}$ in $0.1 \mathrm{M} \mathrm{HNO}_{3}$ but with varying AHA : $\mathrm{Pu}$ ratios gave $E_{\mathrm{f}}$ (vs. SSCE) values for the $\mathrm{Pu}^{\text {IV/III }}$ couple given in Table 3. The value obtained for an AHA : Pu ratio of $6: 1$ is $c a .40 \mathrm{mV}$ greater than that obtained in the preliminary experiment. However the $E_{\mathrm{f}}$ value for the $\left[\mathrm{Fe}(\mathrm{CN})_{6}\right]^{3-/ 4-}$ couple was also found to be ca. $40 \mathrm{mV}$ greater suggesting that the difference is due to a junction potential or other changed feature of the experimental set up used. In some of the solutions the $\mathrm{CV}$ wave of the added $\left[\mathrm{Fe}(\mathrm{CN})_{6}\right]^{3-}$ did not give clearly defined peak potentials so that a similar adjustment could not be applied. Where the potential of the $\left[\mathrm{Fe}(\mathrm{CN})_{6}\right]^{3-/ 4-}$ couple could be determined, adjusted values for the $E_{\mathrm{f}}$ of the $\mathrm{Pu}^{\mathrm{IV} / \mathrm{III}}$ couple

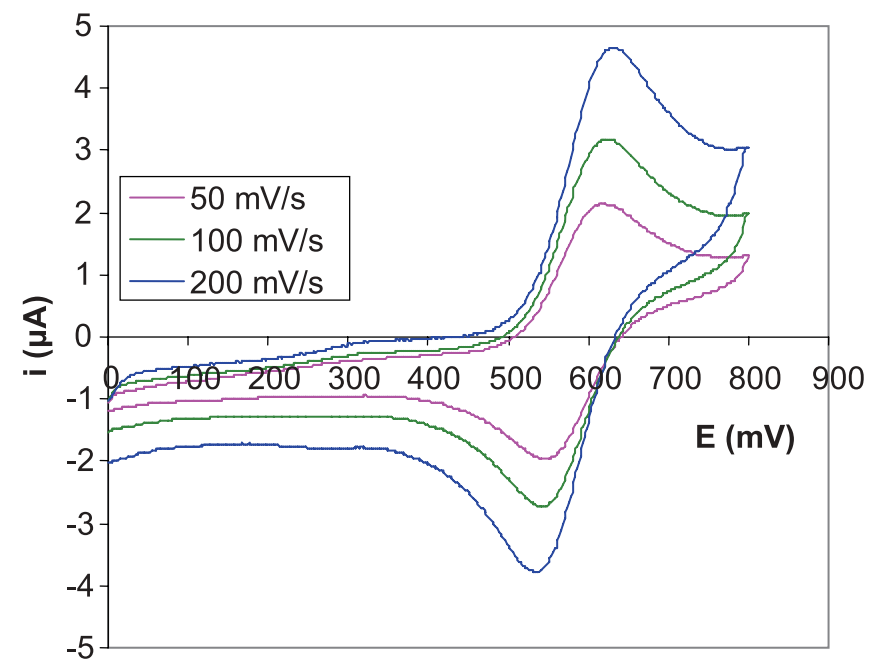

Fig. 9. CVs of a solution containing $0.001 \mathrm{M} \mathrm{Pu}^{4+}$ and $0.006 \mathrm{M}$ AHA in $0.1 \mathrm{M} \mathrm{HNO}_{3}$.

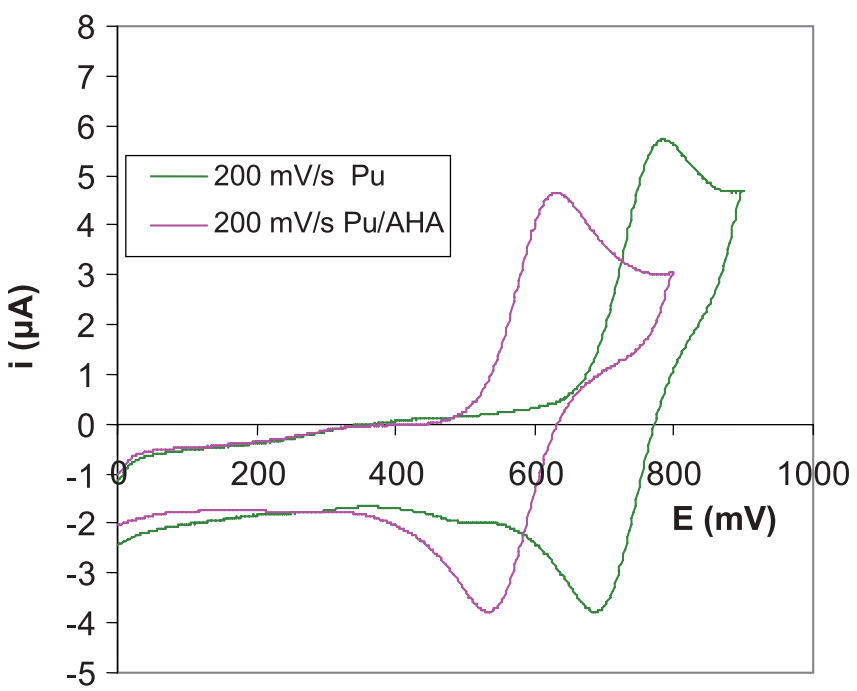

Fig. 10. The shift in potential of the $\mathrm{Pu}^{4+/ 3+}$ couple on the addition of AHA to $\mathrm{Pu}$ in a solution of $0.001 \mathrm{M} \mathrm{Pu}^{4+}$ in $0.1 \mathrm{M} \mathrm{HNO}_{3}$ (AHA : Pu $=6: 1$ ).

are also shown in Table 3. Despite the problems with the accuracy of the potential measurements, the general trend suggests that the potential of the $\mathrm{Pu}^{\mathrm{IV} / \mathrm{III}}$ couple decreases in the presence of AHA to reach an essentially constant value when, or just before, the AHA : Pu ratio reaches $6: 1$. This agreed with the EAS of $0.001 \mathrm{M}$ Pu-AHA solutions which showed absorbance at $441 \mathrm{~nm}\left(\mathrm{Pu}^{\mathrm{IV}}\right.$-AHA complex peak) reaching a plateau at $\sim 6: 1 \mathrm{AHA}: \mathrm{Pu}$ ratio (in $1 \mathrm{M} \mathrm{HNO}_{3}$ ). 
Table 4. The variation in $E_{\mathrm{f}}$ with acidity for solutions containing $0.001 \mathrm{M} \mathrm{Pu}^{4+}$ and $0.01 \mathrm{M}$ AHA.

\begin{tabular}{llllllll}
\hline Acidity & 0.1 & 0.5 & 1.0 & 1.5 & 2.0 & 2.5 & 3.0 \\
\hline$E_{\mathrm{f}}(\mathrm{mV})^{a}$ & 600 & 627 & 646 & 656 & 652 & 656 & 646 \\
\hline
\end{tabular}

a: The $E_{\mathrm{f}}$ values $(v s . \mathrm{Ag} / \mathrm{AgCl})$ quoted here were not corrected for $i R$ drop and this is expected to result in a high bias of between 1 and $5 \mathrm{mV}$ in the values cited.

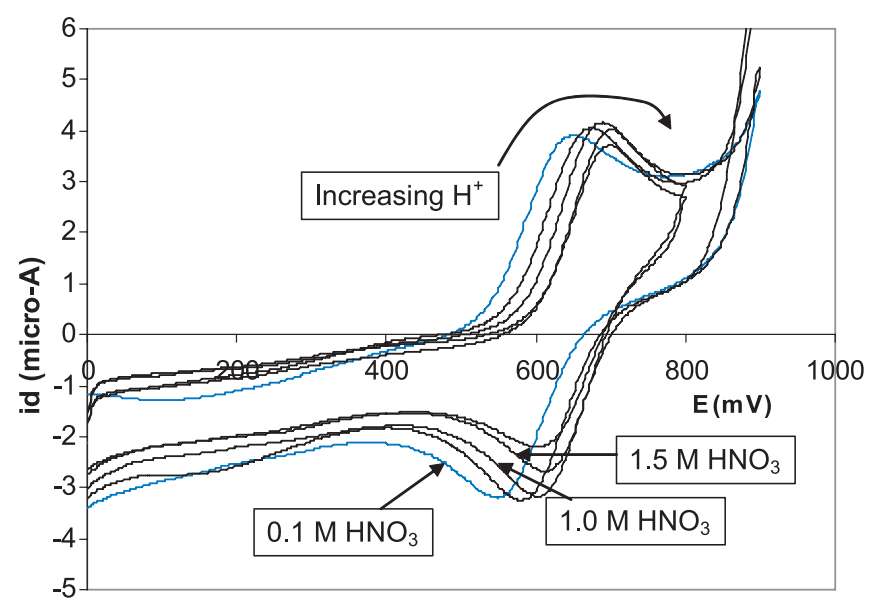

Fig. 11. Selected CVs of solutions containing $0.001 \mathrm{M} \mathrm{Pu}(\mathrm{IV})$ and $0.01 \mathrm{M}$ AHA at varying acidities. Lines correspond to CVs at $0.1,0.5$, $1.0,1.5$ and $3 \mathrm{M} \mathrm{HNO}_{3}$ (data at 2.0 and $2.5 \mathrm{M} \mathrm{HNO}_{3}$ not included).

In order to assess the effect of acidity on the potential of the $\mathrm{Pu}^{\mathrm{IV} / \mathrm{III}}$ couple in the presence of $\mathrm{AHA}$ a series of measurements was made on solutions containing $0.001 \mathrm{M} \mathrm{Pu}^{4+}$ and $0.01 \mathrm{M}$ AHA in various concentrations of acid. Representative examples of the CVs obtained are shown in Fig. 11 and the numerical results in Table 4. Between 0.1 and $1.5 \mathrm{M}$ $\mathrm{HNO}_{3}$ there is a shift in the formal potential of the $\mathrm{Pu}^{\mathrm{IV} / \mathrm{III}}$ couple with increasing acidity towards the value found in the absence of AHA (i.e. $+0.733 \mathrm{~V} v$ s. SSCE). This reflects decomplexation/speciation changes and correlates with the EAS which start to show the presence of small amounts of $\mathrm{Pu}\left(\mathrm{NO}_{3}\right)^{3+}$ (peak at $\sim 476 \mathrm{~nm}$ ) from an acidity of $1.5 \mathrm{M}$ $\mathrm{HNO}_{3}$ upwards. Between 1.5 and $3 \mathrm{M} \mathrm{HNO}_{3}$ there is no consistent change in potential, the values all being in the range $651 \pm 5 \mathrm{mV}$.

\subsubsection{Discussion}

Preliminary speciation diagram calculations indicate that, at $0.008 \mathrm{M}$ total AHA, Pu(IV) exists predominantly as the $1: 1$ $\mathrm{Pu}$ : AHA complex at $1 \mathrm{M} \mathrm{HNO}_{3}$ [28]. In the same system at $0.1 \mathrm{M} \mathrm{HNO}_{3}, \mathrm{Pu}(\mathrm{IV})$ exists as a mix of the $1: 1$ and $1: 2$ $\mathrm{Pu}$ : AHA complexes with the $1: 1$ complex being approximately twice the concentration of the $1: 2$ complex [28]. By use of those equilibrium constants for formation of the $1: 1$ and $1: 2 \mathrm{Pu}(\mathrm{IV})$ : AHA species in nitric acid derived from stability constant measurements in $\mathrm{HClO}_{4}$ [12] and $\mathrm{Pu}(\mathrm{IV})$ nitrate complexation constants [31], it is possible through use of Eq. (9) and the standard electrode potential for the $\mathrm{Pu}^{4+/ 3+}$ couple [32], to calculate the standard electrode potentials for the $\mathrm{Pu}(\mathrm{AHA})^{3+} / \mathrm{Pu}^{3+}$ and $\mathrm{Pu}(\mathrm{AHA})_{2}{ }^{2+} / \mathrm{Pu}^{3+}$ couples:

$$
\begin{aligned}
E_{\mathrm{Pu}(\mathrm{AHA})^{3+} / \mathrm{Pu}^{3+}}^{\theta} & =E_{\mathrm{Pu}^{4+} / \mathrm{Pu}^{3+}}^{\theta}-\frac{R T}{F} \ln K_{1} \\
E_{\mathrm{Pu}(\mathrm{AHA})_{2}^{2+} / \mathrm{Pu}^{3+}}^{\theta} & =E_{\mathrm{Pu}(\mathrm{AHA})^{3+} / \mathrm{Pu}^{3+}}^{\theta}-\frac{R T}{F} \ln K_{2} \\
& =E_{\mathrm{Pu}^{4+} / \mathrm{Pu}^{3+}}^{\theta}-\frac{R T}{F} \ln K_{1} K_{2},
\end{aligned}
$$

where $K_{1}$ and $K_{2}$ are the equilibrium constants for the following systems:

$$
\begin{aligned}
& \mathrm{AHA}+\mathrm{Pu}^{4+} \stackrel{K_{1}}{\longleftrightarrow} \mathrm{Pu}(\mathrm{AHA})^{3+}+\mathrm{H}^{+} \\
& \mathrm{AHA}+\mathrm{Pu}(\mathrm{AHA})^{3+} \stackrel{K_{2}}{\longleftrightarrow} \mathrm{Pu}(\mathrm{AHA})_{2}{ }^{2+}+\mathrm{H}^{+} .
\end{aligned}
$$

This assumes that the complexes are labile and rapid ligand dissociation accompanies reduction. The apparently reversible character of the cyclic voltammograms obtained in the absence of AHA and at AHA : Pu ratios above $5: 1$ suggest that the ligand dissociation reactions are rapid on the cyclic voltammetry timescales studied here and do indeed involve highly labile species. From these calculated standard potentials it is possible to estimate the formal potential, $E_{\mathrm{f}}$, of the $\mathrm{Pu}(\mathrm{AHA})^{3+} / \mathrm{Pu}^{3+}$ and $\mathrm{Pu}(\mathrm{AHA})_{2}{ }^{2+} / \mathrm{Pu}^{3+}$ redox couples by writing the Nernst equation for each couple (incorporating the standard electrode potentials as determined by Eq. (11) and setting $\left[\mathrm{Pu}^{4+}\right],\left[\mathrm{Pu}(\mathrm{AHA})^{3+}\right]$ and $\left[\mathrm{Pu}(\mathrm{AHA})_{2}{ }^{2+}\right]$ therein equal to $\left.1 \mathrm{M}\right)$. This gives:

$$
\begin{gathered}
E_{\mathrm{f}}\left(\mathrm{Pu}(\mathrm{AHA})^{3+} / \mathrm{Pu}^{3+}\right)= \\
E_{\mathrm{Pu}(\mathrm{AHA})^{3+} / \mathrm{Pu}^{3+}}^{\theta}+\frac{R T}{F} \ln \left(\frac{\left[\mathrm{H}^{+}\right]}{[\mathrm{AHA}]}\right) \\
E_{\mathrm{f}}\left(\mathrm{Pu}(\mathrm{AHA})_{2}{ }^{2+} / \mathrm{Pu}^{3+}\right)= \\
E_{\mathrm{Pu}(\mathrm{AHA})_{2}{ }^{2+} / \mathrm{Pu}^{3+}}^{\theta}+\frac{R T}{F} \ln \left(\frac{\left[\mathrm{H}^{+}\right]^{2}}{[\mathrm{AHA}]^{2}}\right),
\end{gathered}
$$

from which can be calculated values of $+0.808 \mathrm{~V}$ and $+0.867 \mathrm{~V}$ (vs. NHE) for the reduction of the $1: 1$ complex in $0.008 \mathrm{M}$ total AHA solutions at 0.1 and $1 \mathrm{M} \mathrm{HNO}_{3}$, respectively; and calculated values of +0.825 and $+0.943 \mathrm{~V}$ (vs. NHE) for the reduction of the $2: 1$ complex in $0.008 \mathrm{M}$ total AHA solutions at 0.1 and $1 \mathrm{M} \mathrm{HNO}_{3}$, respectively.

The measured and calculated formal potentials for the $\mathrm{Pu}^{4+} / \mathrm{HNO}_{3} / \mathrm{AHA}$ system are summarized in Fig. 12. Electrochemical measurements on nitric acid solutions of $\mathrm{Pu}^{4+}$ containing the complexing agent AHA (Table 3) show that the presence of AHA has a stabilising effect on $\mathrm{Pu}^{4+}$ with respect to reduction, this resulting from the complexation of $\mathrm{Pu}^{4+}$ with hydroxamate. The measured shift in the $\mathrm{Pu}^{\mathrm{IV} / \mathrm{III}}$ potential in $0.1 \mathrm{M}$ and $1 \mathrm{M} \mathrm{HNO}_{3}$ when AHA was added in an AHA : Pu ratio of $8: 1$ were 141 and $49 \mathrm{mV}$, respectively.

Fig. 12 also shows that, within experimental error, the measured formal potential of the $8: 1$ AHA : $\mathrm{Pu}$ solution $(+0.858 \mathrm{~V} v s$. NHE) in $1 \mathrm{M}$ nitric acid is barely distinguishable from the onset potential of $+0.861 \mathrm{~V}$ ( $v s$. NHE) reported for AHA oxidation [19], although it should be noted that the latter was obtained at a gold electrode [33], which is not chemically inert under these conditions. Therefore, the potential data summarised in Fig. 12 suggest that AHA itself should reduce free $\mathrm{Pu}^{4+}$ to $\mathrm{Pu}^{3+}$ but cannot reduce either the $1: 1$ or $2: 1$ AHA Pu complexes. 


\section{Measured Values}

\section{Calculated Values}

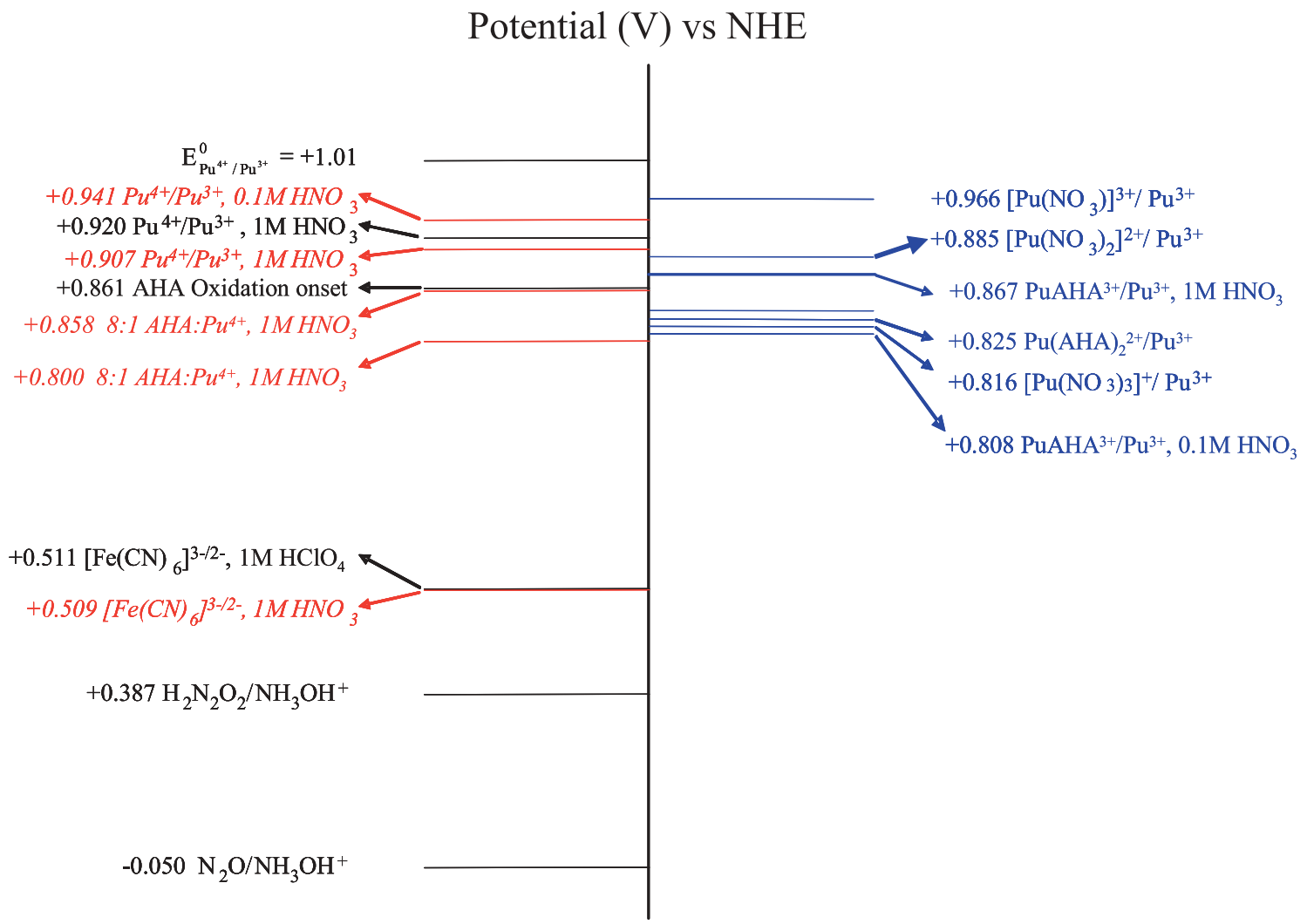

Fig. 12. Schematic potential diagram showing the measured (measured numbers in italic are extracted from this work, those in normal font are from published data) and calculated formal potentials for the $\mathrm{Pu}^{4+} / \mathrm{HNO}_{3} / \mathrm{AHA}$ system.

Comparison of the experimentally determined formal potentials for the $8: 1 \mathrm{AHA}: \mathrm{Pu}$ systems at 0.1 and $1 \mathrm{M} \mathrm{HNO}_{3}$ with the calculated formal potential values for those systems (vide supra and the right hand side of Fig. 12) indicates that the experimentally determined values most closely correspond with the calculated values for the $1: 1$ complex at both nitric acid concentrations. This is in agreement with the preliminary speciation data cited at the beginning of this section.

Thermodynamically, hydroxylamine should reduce $\mathrm{Pu}(\mathrm{IV})$-AHA complexes so the fact that it does not appear to do so in our experiments implies some kinetic hindrance perhaps due to steric constraints. The reductant for $\mathrm{Pu}(\mathrm{IV})$ ions in this $\mathrm{Pu}(\mathrm{IV}) / \mathrm{AHA} / \mathrm{HNO}_{3}$ system therefore seems most likely to be the AHA. Whether this is a reaction between de-complexed $\mathrm{Pu}^{4+}(\mathrm{aq})$ and solution phase AHA or whether it may be as a result of 'internal' electron transfer as a bound hydroxamate ligand hydrolyses in-situ is currently only speculation.

\section{Conclusion}

It is well known that simple hydroxamic acids such as FHA and AHA are unstable in acid solution undergoing acid hydrolysis to form the parent carboxylic acid and hydroxylamine. We have determined the kinetic rate equations for these reactions, including activation energies and nitrate dependencies. These are consistent with the general literature on hydroxamic acid hydrolysis. $\mathrm{Pu}(\mathrm{IV})$ forms strong complexes with these hydroxamate ligands even in acid solutions but these complexes are unstable with $\mathrm{Pu}(\mathrm{III})$ eventually being formed in solution. The reductions of $\mathrm{Pu}(\mathrm{IV})$ in the presence of FHA and AHA have been examined. They are consistent with a mechanism in which free hydroxamic acid in solution is hydrolysed whilst $\mathrm{Pu}(\mathrm{IV})$ ions remain fully complexed to hydroxamate ligands; then at some point close to a $1: 1 \mathrm{Pu}(\mathrm{IV}):$ XHA ratio, some free $\mathrm{Pu}^{4+}$ is released from the complex and reduction is initiated. Electrochemical and kinetic data suggest that the reductant is the hydroxamic acid rather than the hydroxylamine.

Acknowledgment. The authors wish to thank V. Hammel, J. Kay, R. Cooke, G. Brown (Nexia Solutions) for assistance in the course of this work. This work was funded by BNFL and the Nuclear Decommissioning Authority.

\section{References}

1. Chatterjee, B.: Donor properties of hydroxamic acids. Coord. Chem. Rev. 26, 281 (1978).

2. Raymond, K. N., Freeman, G. E., Kappel, M. J.: Actinide specific complexing agents: their structural and solution chemistry. Inorg. Chim. Acta 94, 193 (1984).

3. Anderegg, G., L'Eplattenier, F., Schwarzenbach, G.: Hydroxamatkomplexe II. Die Anwendung der pH-Methode. Helvet. Chim. Acta 46, 1400 (1963).

4. Barocas, A., Baroncelli, F., Biondi, G. B., Grossi, G.: The complexing power of hydroxamic acids and its effect on behaviour of organic extractants in the reprocessing of irradiated fuels-II. J. Inorg. Nucl. Chem. 28, 2961 (1966). 
5. Baroncelli, F., Grossi, G.: The complexing power of hydroxamic acids and its effect on behaviour of organic extractants in the reprocessing of irradiated fuels-I. J. Inorg. Nucl. Chem. $\overline{27}, \overline{1085}$ (1965).

6. Colston, B. J., Choppin, G. R., Taylor, R. J.: A preliminary study of the reduction of $\mathrm{Np}(\mathrm{VI})$ by formohydroxamic acid using stopped-flow near-infrared spectrophotometry. Radiochim. Acta 88, 329 (2000).

7. Chung, D. Y., Lee, E. H.: The reduction of $\mathrm{Np}(\mathrm{VI})$ by acetohydroxamic acid in nitric acid solution. In: Recent Advances in Actinide Science. (Alvarez, R., Bryan, N. D., May, I., eds.) Royal Society of Chemistry, Cambridge (2006), pp. 587-589.

8. Fox, O. D., Jones, C. J., Birkett, J. E., Carrott, M. J., Maher, C. J., Roube, C. V., Taylor, R. J.. Advanced PUREX flowsheets for future $\mathrm{Np}$ and $\mathrm{Pu}$ fuel cycle demands. In: Separations for the $\mathrm{Nu}-$ clear Fuel Cycle in the $21^{\text {st }}$ Century. (Lumetta, G. J., Nash, K. L., Clark, S. B., Friese, J. I., eds.) ACS Symposium Series 933, American Chemical Society, Washington DC (2006), pp. 89-102.

9. Birkett, J. E., Carrott, M. J., Fox, O. D., Jones, C. J., Maher, C. J., Roube, C. V., Taylor, R. J., Woodhead, D. A.: Controlling neptunium and plutonium within single cycle solvent extraction flowsheets for advanced fuel cycles. J. Nucl. Sci. Technol. 44, 337 (2007).

10. Zilberman, B. Ya., Fedorov, Yu. S., Mishin, E. N., Sytnik, L. V., Shmidt, O. V., Kukharev, D. N., Goletsky, N. D., Glekov, R. G., Palenik, Yu. V., Sukhareva, S. Yu.: Superpurex as a TBP-compatible process for recovery and partitioning of long lived radionuclides from NPP spent fuel. In: Proceedings of the International Symposium NUCEF 2001 - Scientific Basis for Criticality Safety, Separation Process and Waste Disposal. (Banba, T., Tsubata, Y., eds.) JAERI-Conf 2002-004, Tokai-Mura (2002), pp. 189-196.

11. Todd, T. A., Wigelund, R. A.: Advanced separation technologies for processing spent nuclear fuel and the potential benefits to a geologic repository. In: Separations for the Nuclear Fuel Cycle in the $21^{\text {st }}$ Century. (Lumetta, G. J., Nash, K. L., Clark, S. B., Friese, J. I., eds.) ACS Symposium Series 933, American Chemical Society, Washington DC (2006), pp. 41-56.

12. Carrott, M. J., Fox, O. D., Maher, C. J., Mason, C., Taylor, R. J., Sinkov, S., Choppin, G. R.: Solvent extraction behaviour of plutonium(IV) ions in the presence of simple hydroxamic acids. Solv. Extr. Ion. Exch. 25, 723 (2007).

13. Miles, J. H., Temple, W.: An analytical method and hydrolysis data for a new $\mathrm{U} / \mathrm{Pu}$ separating reagent. Unpublished report, AEA-FS-0178(H), Harwell (1993).

14. Mane, B. S., Jagdale, M. H.: Kinetics of the acid catalysed hydrolysis of isobutyrohydroxamic acid. J. Ind. Chem. Soc. LIV, 615 (1977).

15. Taylor, R. J., Boxall, C., Andrieux, F., Mason, C.: Modelling the hydrolysis of actinide complexed hydroxamic acid ligands. In: Recent Advances in Actinide Science. (Alvarez, R., Bryan, N. D.,
May, I., eds.) Royal Society of Chemistry, Cambridge (2006), pp. 626-628.

16. Laidler, K. J., Meiser, J. H.: Physical Chemistry. The Benjamin/ Cummings Publishing Company Inc., California (1982).

17. Cohen, D. J.: The absorption spectra of plutonium ions in perchloric acid solutions. Inorg. Nucl. Chem. 18, 211 (1961).

18. May, I., Taylor, R. J., Denniss, I. S., Wallwork, A. L., May, I.: Czech J. Phys. 49, 597 (1999).

19. Taylor, R. J., May, I.: The reduction of actinide ions by hydroxamic acids. Czech J. Phys. 49, 617 (1999).

20. Barney, G. S.: A kinetic study of the reaction of plutonium(IV) with hydroxylamine. J. Inorg. Nucl. Chem. 38, 1677 (1976).

21. Bard, A. J., Parsons, R., Jordon, J.: Standard Potentials in Aqueous Solution. Marcel Dekker, New York (1985).

22. Ghosh, K. K.: Kinetic and mechanistic aspects of acid-catalysed hydrolysis of hydroxamic acids. Ind. J. Chem. 36B, 1089 (1997).

23. Mane, B. S., Jagdale, M. H.: Kinetics of the acid catalysed hydrolysis of hexanohydroxamic acid. Ind. J. Chem. 15A, 1086 (1977).

24. Mane, B. S., Jagdale, M. H.: Kinetics of the acid catalyzed hydrolysis of hydroxamic acids. React. Kinet. Catal. Lett. 6, 417 (1977).

25. Karraker, D. G., Rudisill, T. S., Thompson, M. C.: Studies of the effect of acetohydroxamic acid on plutonium and neptunium by 30 vol. \% tributyl phosphate. WSRC-TR-2001-00509, Westinghouse Savannah River Company, http://www.osti.gov/bridge/.

26. Miles, J. H.: Separation of plutonium and uranium. In: Science and Technology of Tributyl Phosphate, Volume III. (Schulz, W. W., Burger, L. L., Navratil, J. D., eds.) CRC Press Inc., Boca Raton (1990), pp. 11-54.

27. Taylor, R. J., Mason, C., Cooke, R., Boxall, C.: The reduction of $\mathrm{Pu}(\mathrm{IV})$ by formohydroxamic acid in nitric acid. J. Nucl. Sci. Technol. Suppl. 3, 278 (2002).

28. Andrieux, F. P. L., Boxall, C., Taylor, R. J.: The hydrolysis kinetics of hydroxamic acid complexants in the presence of oxidising plutonium(IV). Inorg. Chem., under review (2008).

29. Koltunov, V. S., Zhuravleva, G. I.: Kinetics of actinide reduction by hydroxylamine. III. Plutonium(IV) reduction in nitric acid solution. Radiokhim. 20, 94 (1978).

30. Koltunov, V. S., Zhuravleva, G. I.: Kinetics of actinide reduction by hydroxylamine. IV. Plutonium(IV) reduction in perchloric acid solution. Radiokhim. 20, 661 (1978).

31. Clark, D. L., Hecker, S. S., Jarvinen, G. D., Neu, M. P.: Plutonium. In: The Chemistry of the Actinide and Transactinide Elements. (Morss, L. R., Edelstein, N. M., Fuger, J. R., eds.) $3^{\text {rd }}$ Edn., Springer, Dordrecht (2006), pp. 813-1265.

32. Bard, A. J., Faulkner, J. R.: Electrochemical Methods Fundamentals and Applications. J. Wiley \& Sons, New York (1980).

33. Shackleford, S.: Development of an EQCM-based sensor for metal ions. Ph.D. Thesis, University of Central Lancashire, Preston (2002). 